\title{
Identification and Distribution of Fungi Associated with Fairy Rings on Golf Putting Greens
}

\author{
G. L. Miller, L. F. Grand, and L. P. Tredway, Department of Plant Pathology, North Carolina State University, Raleigh 27695
}

\begin{abstract}
Miller, G. L., Grand, L. F., and Tredway, L. P. 2011. Identification and distribution of fungi associated with fairy rings on golf putting greens. Plant Dis. 95:1131-1138.

Traditional methods for identification of fairy ring fungi rely on the morphology of mature basidiocarps, which are ephemeral and often do not reach maturity on golf greens due to management practices. From 2007 to 2009, basidiocarps and soil samples were collected from 15 hybrid bermudagrass and 30 bentgrass greens exhibiting fairy ring symptoms in California, Florida, Hawaii, Illinois, Oklahoma, North Caroline, South Carolina, and Wisconsin. Genomic DNA was extracted from 122 unknown samples. Extractions were made from mycelium isolated from puffball or mushroom tissue, from mycelium isolated from a soil block, or through direct DNA extraction from infested soil. DNA also was extracted from 16 reference isolates. The internal tran-

scribed spacer (ITS) region of ribosomal DNA was amplified and sequenced using the basidiomycete-specific primer sets ITS1f/ITS $4 \mathrm{~b}$ and Basid0001/2R. Phylogenetic trees were constructed with the neighborjoining algorithm, with nodes evaluated by bootstrap analysis. Most samples grouped into one of three clades corresponding to species within the family Lycoperdaceae: Arachnion album, Bovista dermoxantha, and Vascellum curtisii. Although over 60 different basidiomycetes have been associated with fairy rings in turfgrasses, relatively few species were found on golf putting greens in this study. Presently, DNA sequencing may be the most efficient method for attempting speciation of fairy ring fungi from infested soil.
\end{abstract}

Fairy rings have been reported on all grass types and in all regions of the world (33). On highly maintained grasses, such as those used on lawns, golf courses, and athletic fields, fairy rings can cause severe symptoms of wilting or plant death in rings or arcs that range 10 to $30 \mathrm{~cm}$ wide but mostly are from 4.5 to $9 \mathrm{~m}$ in diameter (8). Under the classification system of Shantz and Piemesel (31), fairy ring types of the severe, necrotic nature are referred to as type I, fairy rings that only exhibit stimulated grass growth are referred to as type II, and rings of basidiocarps are referred to as type III. Fairy rings are additionally termed superficial when the fungi primarily reside in the upper thatch layer. Fungi associated with superficial fairy rings have been implicated as causal agents of localized dry spots on golf course greens $(9,44)$.

Nearly 60 different species of basidiomycete fungi have been implicated in fairy ring occurrence $(8,17,30,31,33,38)$ but seldom is the responsible species identified in a given circumstance. Identification of basidiomycete fungi associated with fairy rings has been historically based on morphological characteristics of basidiocarps and basidiospores $(8,18,33)$. On golf putting greens, basidiocarp formation is ephemeral and may not occur in association with fairy ring symptoms. Also, agronomic practices such as frequent and low mowing do not allow the basidiocarp to mature to a stage needed for identification. For this reason, the diversity of fairy ring fungi on putting greens is not adequately known, and many studies regarding fairy rings are performed without speciation of the causal agent $(4,12-14,24,35)$.

Fungal diversity in soil ecosystems has also been studied with an indirect method involving the isolation of spores and mycelia in culture from soil samples (28). Culture-based methods of surveying basidiomycetes from soils are problematic for several reasons. The technique is biased largely toward detecting fungi that grow rapidly in culture. Many basidiomycete fungi grow slowly in culture and, for this reason, faster-growing ascomycete and zygomy-

Corresponding author: G. L. Miller, E-mail: turfpath@missouri.edu

Accepted for publication 18 April 2011.

doi:10.1094/PDIS-11-10-0800

(C) 2011 The American Phytopathological Society cete species are common contaminants (43). Second, a large number of basidiomycetes are not culturable using standard techniques $(15,23,28,40)$. Last, hyphal characters are insufficient to identify a basidiomycete fungal species. The presence of clamp connections is often used to identify fungal hyphae as a basidiomycete but many basidiomycetes, particularly most in the family Lycoperdaceae, do not form clamp connections (11).

Studies using the polymerase chain reaction (PCR) and other modern molecular techniques have examined microbial diversity in soil samples. DNA fingerprinting techniques, such as restriction fragment length polymorphisms, have proven useful to distinguish individuals but provide limited utility for speciation compared with sequence analysis (6). In particular, several studies have adopted DNA sequence-based techniques to examine the diversity of uncultured basidiomycetes in agricultural soils and forest ecosystems $(5,23,26,28)$.

There is a lack of systematic characterization of the causal fungi of fairy rings on golf putting greens. The different fungi involved could have varying susceptibility to fungicide chemistries, making proper fungicide selection dependent on accurate identification. Fairy ring pathogens may also differ in aspects of their life cycle, such as optimal growth temperature or depth of soil inhabitation, which could impact the optimal timing or method of fungicide application. The objectives of this study were to develop identification techniques for fairy ring fungi combining traditional and DNA-based methodologies and implement these techniques to determine the species of these fungi found on putting greens in North Carolina and other selected states.

\section{Materials and Methods}

Sample collection. From 2007 to 2009, one to two samples of turf (10.8 cm in diameter, approximately $10.2 \mathrm{~cm}$ deep) were taken along the margin of type I and type II fairy rings occurring on 15 hybrid bermudagrass (Cynodon dactylon (L.) Pers. $\times$ C. transvaalensis Burtt-Davy) and 30 bentgrass (Agrostis spp. L.) putting greens at 35 golf course and university research sites in California $(n=3)$, Florida $(n=6)$, Hawaii $(n=1)$, Illinois $(n=2)$, Indiana $(n$ $=1)$, North Carolina $(n=16)$, Oklahoma $(n=1)$, South Carolina $(n$ $=3$ ), Virginia $(n=1)$, and Wisconsin $(n=1)$ (Table 1). Samples were obtained from different putting greens at sites $13(n=2), 15$ $(n=2), 21(n=2), 22(n=2)$, and $24(n=3)$. Sampled greens were 
established with creeping bentgrass (Agrostis stolonifera L. 'A-1' [ $n=11]$, 'A-4' $[n=2]$, 'A-1/A-4' $[n=9]$, 'Crenshaw' $[n=1]$, 'L93' $[n=1]$, 'Penncross' $[n=3]$, and 'Pennlinks' $[n=1])$, Poa annua/creeping bentgrass (unknown cultivar $[n=1]$ ), velvet bentgrass (A. canina L., 'SR7200' $[n=1]$ ), or hybrid bermudagrass ('Champion' $[n=1]$, 'Tifdwarf' $[n=3]$, and 'Tifeagle $[n=11])$. In all, 53 basidiocarps representing puffball-type $(n=50)$ and mushroom-type $(n=3)$ morphology were also collected in association with fairy ring symptoms. Most basidiocarps $(n=29)$ were collected from symptomatic areas in 2007 and 2009 at the Lake Wheeler Turf Research Facility in Raleigh, NC (site 16) on three research greens consisting of Penncross creeping bentgrass $(n=9)$, A-4 creeping bentgrass $(n=8)$, and Tifeagle hybrid bermudagrass $(n=12)$.

Sixteen total reference isolates of species representing known fairy ring genera were acquired (Table 2). Seven reference isolates were acquired from the American Type Culture Collection (Manas- sas, VA), four isolates were supplied from the collections of $\mathrm{M}$. Fidanza (Penn State University, Reading, PA) and Y. Terashima (Chiba Prefectural Forest Research Center, Japan), and five basidiocarps were collected from sites in North Carolina exhibiting fairy ring symptoms in turf not used for putting greens. Basidiocarps were examined morphologically as described below, and identified to species using several keys and field guides $(1,7,25,32)$.

Morphological studies. If possible, basidiocarps were identified morphologically to species according to the description of Coker and Couch (7) or Kriesel (21). Fresh or dried fully mature basidiocarps were used for morphological examination. Peridium and gleba structure were observed with a dissecting microscope at $\times 20$ to $\times 40$. Micromorphological data was gathered with a compound light microscope at $\times 400$ to $\times 1,000$. Observation of characters such as spore ornamentation and capillitial structure were made from glebal or gill material mounted in $3 \% \mathrm{KOH}$. Spores and capillitia

Table 1. Plant host species, origin, DNA source, and ribosomal DNA (rDNA) clade for sequences obtained from putting greens exhibiting fairy ring symptoms

\begin{tabular}{|c|c|c|c|c|c|}
\hline Sequence & Site & Host species & Origin & DNA source & rDNA clade ${ }^{z}$ \\
\hline CASX1 & 1 & Annual bluegrass/Creeping bentgrass & Canyon Lake, CA & Soil & N/A \\
\hline CASX2 & 2 & Velvet bentgrass & Niporno, $\mathrm{CA}$ & Soil & N/A \\
\hline CASX3 & 3 & Creeping bentgrass & San Diego, CA & Soil & A \\
\hline CAP1 & 3 & Creeping bentgrass & San Diego, CA & Basidiocarp & A \\
\hline FLSB1 & 4 & Bermudagrass & Orlando, FL & Mycelia & A \\
\hline FLSB2 & 5 & Bermudagrass & Port St. Lucie, FL & Mycelia & A \\
\hline FLSB3 & 6 & Bermudagrass & Naples, FL & Mycelia & A \\
\hline FLSX1 & 7 & Bermudagrass & Naples, FL & Soil & A \\
\hline FLSX2 & 8 & Bermudagrass & Ft. Myers, FL & Soil & A \\
\hline FLSX3 & 9 & Bermudagrass & Lake Placid, FL & Soil & B \\
\hline HIP1 & 10 & Bermudagrass & Kapalua, HI & Basidiocarp & $\mathrm{C}$ \\
\hline HISB1 & 10 & Bermudagrass & Kapalua, HI & Mycelia & $\mathrm{C}$ \\
\hline ILSB1 & 11 & Creeping bentgrass & Glenview, IL & Mycelia & A \\
\hline ILSX1 & 12 & Creeping bentgrass & Hinsdale, IL & Soil & $\mathrm{D}$ \\
\hline INSX1 & 13 & Creeping bentgrass & Laconia, IN & Soil & A \\
\hline INSX2 & 13 & Creeping bentgrass & Laconia, IN & Soil & A \\
\hline NCP1 & 14 & Bermudagrass & Fayetteville, NC & Basidiocarp & $\mathrm{C}$ \\
\hline NCP2 & 15 & Creeping bentgrass & Wilmington, $\mathrm{NC}$ & Basidiocarp & B \\
\hline NCP3 & 16 & Bermudagrass & Raleigh, NC & Basidiocarp & $\mathrm{C}$ \\
\hline NCP4 & 16 & Bermudagrass & Raleigh, NC & Basidiocarp & $\mathrm{C}$ \\
\hline NCP5 & 16 & Bermudagrass & Raleigh, NC & Basidiocarp & $\mathrm{C}$ \\
\hline NCP6 & 16 & Bermudagrass & Raleigh, NC & Basidiocarp & N/A \\
\hline NCP7 & 16 & Bermudagrass & Raleigh, NC & Basidiocarp & $\mathrm{C}$ \\
\hline NCP8 & 16 & Bermudagrass & Raleigh, NC & Basidiocarp & $\mathrm{C}$ \\
\hline NCP9 & 16 & Bermudagrass & Raleigh, NC & Basidiocarp & $\mathrm{C}$ \\
\hline NCP10 & 16 & Bermudagrass & Raleigh, NC & Basidiocarp & $\mathrm{C}$ \\
\hline NCP11 & 16 & Bermudagrass & Raleigh, NC & Basidiocarp & $\mathrm{C}$ \\
\hline NCP12 & 16 & Bermudagrass & Raleigh, NC & Basidiocarp & $\mathrm{C}$ \\
\hline NCP13 & 16 & Bermudagrass & Raleigh, NC & Basidiocarp & $\mathrm{C}$ \\
\hline NCP14 & 16 & Bermudagrass & Raleigh, NC & Basidiocarp & N/A \\
\hline NCP15 & 16 & Creeping bentgrass & Raleigh, NC & Basidiocarp & B \\
\hline NCP16 & 16 & Creeping bentgrass & Raleigh, NC & Basidiocarp & A \\
\hline NCP17 & 16 & Creeping bentgrass & Raleigh, NC & Basidiocarp & $\mathrm{C}$ \\
\hline NCP18 & 16 & Creeping bentgrass & Raleigh, NC & Basidiocarp & $\mathrm{C}$ \\
\hline NCP19 & 16 & Creeping bentgrass & Raleigh, NC & Basidiocarp & $\mathrm{C}$ \\
\hline NCP20 & 16 & Creeping bentgrass & Raleigh, NC & Basidiocarp & N/A \\
\hline NCP21 & 16 & Creeping bentgrass & Raleigh, NC & Basidiocarp & $\mathrm{C}$ \\
\hline NCP22 & 16 & Creeping bentgrass & Raleigh, NC & Basidiocarp & $\mathrm{C}$ \\
\hline NCP23 & 16 & Creeping bentgrass & Raleigh, NC & Basidiocarp & $\mathrm{B}$ \\
\hline NCP24 & 16 & Creeping bentgrass & Raleigh, NC & Basidiocarp & $\mathrm{C}$ \\
\hline NCP25 & 16 & Creeping bentgrass & Raleigh, NC & Basidiocarp & $\mathrm{C}$ \\
\hline NCP26 & 16 & Creeping bentgrass & Raleigh, NC & Basidiocarp & $\mathrm{C}$ \\
\hline NCP27 & 16 & Creeping bentgrass & Raleigh, NC & Basidiocarp & A \\
\hline NCP28 & 16 & Creeping bentgrass & Raleigh, NC & Basidiocarp & B \\
\hline NCP29 & 16 & Creeping bentgrass & Raleigh, NC & Basidiocarp & $\mathrm{C}$ \\
\hline NCP30 & 16 & Creeping bentgrass & Raleigh, NC & Basidiocarp & B \\
\hline NCP31 & 16 & Creeping bentgrass & Raleigh, NC & Basidiocarp & $\mathrm{C}$ \\
\hline NCP33 & 17 & Creeping bentgrass & Durham, NC & Basidiocarp & A \\
\hline NCP34 & 17 & Creeping bentgrass & Durham, NC & Basidiocarp & A \\
\hline NCP35 & 17 & Creeping bentgrass & Durham, NC & Basidiocarp & A \\
\hline \multirow[t]{2}{*}{ NCP36 } & 18 & Creeping bentgrass & Wilmington, NC & Basidiocarp & $\mathrm{E}$ \\
\hline & & & & & (continued on next page) \\
\hline
\end{tabular}

${ }^{\mathrm{z}}$ Clade designated in phylograms found in Figures 1, 2, and 3. N/A = sample sequence not resolved to a clade containing a known fairy ring causing species. 
were mounted in cotton blue (1\% [wt/vol] cotton blue in lactic acid and phenol) for observation. Capillitium or paracapillitium were characterized based on width, shape, color, sclerification, branching pattern, and presence of pits or pores. To obtain a spore print, the pileus of mushroom-type basidiocarps were cut from the stipe and placed on a piece of 9-cm-diameter white filter paper (Thermo Fisher Scientific Inc., Fair Lawn, NJ) at room temperature $\left(21^{\circ} \mathrm{C}\right)$ for $24 \mathrm{~h}$. Spores were measured excluding ornamentation and were characterized based on width, shape, color, presence of a pedicel, size, and ornamentation. Diameter of spores and capillitial threads and pedicel length were measured at $\times 400$ and calculated as the range of 10 arbitrarily selected structures.

Soil DNA extraction. Soil DNA extraction was performed as described by Lynch and Thorn (23), with modifications. Sixty-one samples from putative fairy ring infested soil were assayed, including seven additional samples acquired from a Penncross $(n=3)$ and A-4 $(n=4)$ creeping bentgrass green at site 16. Subsamples of
$10 \mathrm{~g}$ were excised from the mat layer with an 11-mm-diameter cork borer at a $2.5-\mathrm{cm}$ depth, targeting orange coloration or organic matter degradation if apparent. The subsamples were suspended in $150 \mathrm{ml}$ of $0.1 \mathrm{M}$ sodium pyrophosphate, shaken for $5 \mathrm{~min}$, and washed with tap water through sieves with openings of 850,250 , and $63 \mu \mathrm{m}$ to remove bacteria and most fungal spores and maximize yield of target DNA. Sieves were rinsed with tap water and sterilized with $70 \%$ ethanol between samples. DNA was extracted with a PowerSoil DNA kit (MoBio Laboratories, Inc., Solana Beach, CA) from $0.25 \mathrm{~g}$ of washed organic material collected on the $63-\mu \mathrm{m}$ sieve, because previous researchers detected the greatest diversity of fungi in this 63 - to $250-\mu \mathrm{m}$ size range $(2,40)$. Particle washing removed most bacteria and spores of nontarget organisms such as ascomycetes and zygomycetes, and the use of sodium pyrophosphate to disperse soil colloids reduced the amount of washing required to achieve this effect $(23,40)$. DNA was extracted with the above procedure from four additional cup cutter plugs

Table 1. (continued from preceding page)

\begin{tabular}{|c|c|c|c|c|c|}
\hline Sequence & Site & Host species & Origin & DNA source & rDNA clade ${ }^{z}$ \\
\hline NCP37 & 18 & Creeping bentgrass & Wilmington, NC & Basidiocarp & $\mathrm{E}$ \\
\hline NCP38 & 18 & Creeping bentgrass & Wilmington, $\mathrm{NC}$ & Basidiocarp & $\mathrm{E}$ \\
\hline NCP39 & 19 & Creeping bentgrass & Jackson Springs, NC & Basidiocarp & $\mathrm{C}$ \\
\hline $\mathrm{NCP} 40$ & 19 & Creeping bentgrass & Jackson Springs, NC & Basidiocarp & $\mathrm{C}$ \\
\hline NCP41 & 19 & Creeping bentgrass & Jackson Springs, NC & Basidiocarp & $\mathrm{C}$ \\
\hline NCP42 & 19 & Creeping bentgrass & Jackson Springs, NC & Basidiocarp & $\mathrm{C}$ \\
\hline NCP43 & 19 & Creeping bentgrass & Jackson Springs, NC & Basidiocarp & $\mathrm{C}$ \\
\hline NCP44 & 19 & Creeping bentgrass & Jackson Springs, NC & Basidiocarp & $\mathrm{C}$ \\
\hline $\mathrm{NCP} 45$ & 19 & Creeping bentgrass & Jackson Springs, NC & Basidiocarp & $\mathrm{C}$ \\
\hline NCP46 & 20 & Bermudagrass & Wilmington, $\mathrm{NC}$ & Basidiocarp & A \\
\hline NCP47 & 20 & Bermudagrass & Wilmington, NC & Basidiocarp & B \\
\hline NCP48 & 20 & Bermudagrass & Wilmington, $\mathrm{NC}$ & Basidiocarp & A \\
\hline NCP49 & 20 & Bermudagrass & Wilmington, NC & Basidiocarp & $\mathrm{C}$ \\
\hline NCP50 & 34 & Bermudagrass & New Bern, NC & Basidiocarp & B \\
\hline NCSB1 & 35 & Creeping bentgrass & Durham, NC & Mycelia & $\mathrm{C}$ \\
\hline NCSB2 & 21 & Bermudagrass & Rocky Mount, NC & Mycelia & $\mathrm{D}$ \\
\hline NCSB3 & 21 & Bermudagrass & Rocky Mount, NC & Mycelia & N/A \\
\hline NCSB4 & 22 & Creeping bentgrass & Raleigh, NC & Mycelia & C \\
\hline NCSB5 & 22 & Creeping bentgrass & Raleigh, NC & Mycelia & $\mathrm{C}$ \\
\hline NCSB6 & 16 & Creeping bentgrass & Raleigh, NC & Mycelia & $\mathrm{C}$ \\
\hline NCSB7 & 23 & Creeping bentgrass & Morehead City, NC & Mycelia & A \\
\hline NCSB8 & 24 & Creeping bentgrass & Asheboro, NC & Mycelia & $\mathrm{C}$ \\
\hline NCSB9 & 24 & Creeping bentgrass & Asheboro, NC & Mycelia & $\mathrm{C}$ \\
\hline NCSB10 & 25 & Creeping bentgrass & Charlotte, NC & Mycelia & A \\
\hline NCSB11 & 26 & Creeping bentgrass & Sanford, NC & Mycelia & N/A \\
\hline NCSX1 & 35 & Creeping bentgrass & Durham, NC & Soil & $\mathrm{C}$ \\
\hline NCSX2 & 14 & Bermudagrass & Fayetteville, NC & Soil & $\mathrm{C}$ \\
\hline NCSX3 & 15 & Creeping bentgrass & Wilmington, $\mathrm{NC}$ & Soil & A \\
\hline NCSX4 & 16 & Creeping bentgrass & Raleigh, NC & Soil & $\mathrm{C}$ \\
\hline NCSX5 & 16 & Creeping bentgrass & Raleigh, NC & Soil & $\mathrm{B}$ \\
\hline NCSX6 & 16 & Creeping bentgrass & Raleigh, NC & Soil & B \\
\hline NCSX7 & 16 & Creeping bentgrass & Raleigh, NC & Soil & N/A \\
\hline NCSX8 & 16 & Creeping bentgrass & Raleigh, NC & Soil & N/A \\
\hline NCSX9 & 16 & Creeping bentgrass & Raleigh, NC & Soil & N/A \\
\hline NCSX10 & 16 & Creeping bentgrass & Raleigh, NC & Soil & $\mathrm{C}$ \\
\hline NCSX11 & 16 & Creeping bentgrass & Raleigh, NC & Soil & B \\
\hline NCSX12 & 16 & Creeping bentgrass & Raleigh, NC & Soil & N/A \\
\hline NCSX13 & 16 & Creeping bentgrass & Raleigh, NC & Soil & $\mathrm{C}$ \\
\hline NCSX14 & 16 & Creeping bentgrass & Raleigh, NC & Soil & $\mathrm{C}$ \\
\hline NCSX15 & 16 & Creeping bentgrass & Raleigh, NC & Soil & $\mathrm{C}$ \\
\hline NCSX16 & 17 & Creeping bentgrass & Durham, NC & Soil & A \\
\hline NCSX17 & 27 & Creeping bentgrass & New London, NC & Soil & $\mathrm{C}$ \\
\hline NCSX18 & 24 & Creeping bentgrass & Asheboro, NC & Soil & $\mathrm{C}$ \\
\hline NCSX19 & 24 & Creeping bentgrass & Asheboro, NC & Soil & $\mathrm{C}$ \\
\hline NCSX20 & 24 & Creeping bentgrass & Asheboro, NC & Soil & B \\
\hline NCSX21 & 25 & Creeping bentgrass & Charlotte, NC & Soil & A \\
\hline NCSX22 & 20 & Bermudagrass & Wilmington, $\mathrm{NC}$ & Soil & $\mathrm{C}$ \\
\hline OKSB1 & 28 & Creeping bentgrass & Tulsa, OK & Mycelia & $\mathrm{E}$ \\
\hline SCP1 & 29 & Bermudagrass & Myrtle Beach, SC & Basidiocarp & $\mathrm{B}$ \\
\hline SCP2 & 30 & Bermudagrass & Hilton Head, SC & Basidiocarp & A \\
\hline SCSB1 & 31 & Creeping bentgrass & Myrtle Beach, SC & Mycelia & N/A \\
\hline VASX1 & 32 & Creeping bentgrass & Suffolk, VA & Soil & $\mathrm{C}$ \\
\hline WISB1 & 33 & Creeping bentgrass & Wisconsin Rapids, WI & Mycelia & A \\
\hline WISX1 & 33 & Creeping bentgrass & Wisconsin Rapids, WI & Soil & A \\
\hline
\end{tabular}


collected from asymptomatic areas. These samples (NCSX7, NCSX8, NCSX9, and NCSX12) served as negative controls to ensure that DNA amplification of fairy ring fungi did not occur in non-fairy-ring-infested soils.

Isolation from basidiocarps. Pure cultures were obtained from all collected unknown and reference basidiocarps. Small pieces of the gleba from puffball-type basidiocarps or the stipe of mushroom-type basidiocarps were excised with sterile forceps and placed on amended Leonian agar (ALA). The basal medium of ALA contained $1.25 \mathrm{~g}$ of $\mathrm{KH}_{2} \mathrm{PO}_{4}, 0.625 \mathrm{~g}$ of $\mathrm{MgSO}_{4} \cdot 7 \mathrm{H}_{2} \mathrm{O}$ and peptone, $6.25 \mathrm{~g}$ of maltose and malt extract, and $15 \mathrm{~g}$ of Bacto agar (Difco Laboratories, Detroit) (22) per liter of distilled water. The basal medium was autoclaved and cooled to $55^{\circ} \mathrm{C}$, when the following was added aseptically: $50 \mathrm{mg}$ each of chloramphenicol (Sigma-Aldrich, St. Louis), streptomycin sulfate (Sigma-Aldrich), and tetracycline (Sigma-Aldrich) and $2 \mathrm{mg}$ of technical-grade benomyl (methyl 1-[butylcarbamoyl]-2-benzimidazole-carbamate) (Sigma-Aldrich). Except as indicated, all chemicals were obtained from Thermo Fisher Scientific Inc.. The basal medium has been reported as a suitable culture medium for basidiomycete mycelium growth (36) and the amendments specifically inhibit potential bacteria and fungal contaminants (40). Because of these characteristics, ALA was used to maintain cultures and also as a selective medium for soil isolation attempts.

Isolation from soil. Isolation was attempted from mycelium recovered from a soil block method and from plating of washed organic matter. Samples of symptomatic turf $(10.8 \mathrm{~cm}$ in diameter, approximately $10.2 \mathrm{~cm}$ deep) were sliced longitudinally into four sections and placed into a humidity chamber consisting of a rectangular plastic container ( 29 by 19.5 by $7 \mathrm{~cm}$ ) lined with paper towels moistened with sterilized distilled water. The samples were inspected daily for 28 days for mycelium appearance, which usually occurred after 7 to 14 days of incubation. Visible mycelium was subsequently transferred to ALA medium. Washed organic material $(0.25 \mathrm{~g})$ obtained from the previously described soil sieving and washing procedure was spread thinly with a sterile loop on modified Leonian medium. Isolated fungal colonies were examined at $\times 400$ magnification for the presence of clamp connections or identifiable asexual or sexual structures.

Molecular characterization. Genomic DNA from 72 unknown isolates (53 isolates from basidiocarps and 19 from soil blocks) and 16 reference isolates was extracted using the Easy-DNA Kit (Invitrogen Corp., Carlsbad, CA). PCR amplification of ribosomal (r)DNA internal transcribed spacer (ITS) regions ITS1 and 5.8S rRNA and ITS2 was performed on 122 DNA extracts from isolates and soil using the universal fungal primers ITS5 and ITS4 and the basidiomycete-specific primers ITS1f and ITS4b (16). To investigate higher-level taxa relationships, PCR amplification of a larger region, including approximately $1,000 \mathrm{bp}$ of both the nuclear small-subunit (nSSU) rDNA and nuclear large-subunit (nLSU) rDNA, was performed on a subset of 43 DNA extracts using basidiomycete-specific primers Basid-2R and Basid001 (23). PCR reactions were $50 \mu \mathrm{l}$ in volume and consisted of $20 \mathrm{mM}$ Tris- $\mathrm{HCl}$ (pH 8.3), $50 \mathrm{mM} \mathrm{KCl}, 1.5 \mathrm{mM} \mathrm{MgCl} 2,200 \mu \mathrm{M}$ each dNTP, 200 $\mathrm{nM}$ each primer, $1.5 \mathrm{U}$ of Taq polymerase (Bioline Inc., Taunton, MA), and 50 ng of genomic DNA. Thermal cycling conditions for ITS primers involved an initial denaturation step at $94^{\circ} \mathrm{C}$ for $1 \mathrm{~min}$; followed by 32 cycles of $94^{\circ} \mathrm{C}$ for $30 \mathrm{~s}, 55^{\circ} \mathrm{C}$ for $1 \mathrm{~min}$, and $72^{\circ} \mathrm{C}$ for $1 \mathrm{~min}$; and a final extension step at $72^{\circ} \mathrm{C}$ for $2 \mathrm{~min}$. Thermal cycling conditions for Basid primers involved an initial denaturation step at $95^{\circ} \mathrm{C}$ for $2 \mathrm{~min}$; followed by 32 cycles of $94^{\circ} \mathrm{C}$ for $30 \mathrm{~s}$, $55^{\circ} \mathrm{C}$ for $30 \mathrm{~s}$, and $72^{\circ} \mathrm{C}$ for $2 \mathrm{~min}$; and a final extension step at $72^{\circ} \mathrm{C}$ for $7 \mathrm{~min}$. Amplification products were purified with a QIAquick PCR Purification Kit (Qiagen Inc., Valencia, CA) and sent to the Duke University DNA Sequencing Facility (Durham, NC) for cleanup, electrophoresis, and fluorometric analysis. The consensus sequence for each isolate was determined from one to two reactions each with each primer set. A BLAST search of GenBank was performed with each sequence. For each sample, one or two of the most similar sequences based on maximal identity percentage were downloaded for comparison. All sequences were aligned using the ClustalW method in MegAlign (7.1; DNASTAR Inc., Madison, WI) and adjusted by visual examination. Phylogenetic trees were constructed in MEGA 2.1 (37) using the neighborjoining algorithm from genetic distances calculated using the $\mathrm{Ki}$ mura two-parameter model analysis. Bootstrap support at branch nodes was based on 1,000 random samples of the data set. Due to the similarity in sequences, $T$. squamosum DQ415732 was used as an outgroup for trees examining the ITS region.

\section{Results}

Morphology. In all, 8 of the 53 basidiocarp samples (HIP1, NCP2, NCP9, NCP28, NCP34, NCP49, SCP1, and SCP2) were fully mature and suitable for speciation based on basidiocarp morphology. The three unknown mushroom-type basidiocarps associated with fairy rings at site 18 were not mature and unsuitable for speciation. Sequenced amplicons from the primer set ITS1f and ITS4b of morphologically identified species were deposited in GenBank as accession numbers HQ235043 to HQ235050. Three species of Lycoperdaceae were identified:

Arachnion album Schwein. (7,20). Samples NCP2, NCP28, and SCP1. Basidiocarp globose, sessile, 1.0 to $1.5 \mathrm{~cm}$ in diameter.

Table 2. Origin, host or habitat, and fungal species of reference isolates used in phylogenetic comparison to samples ${ }^{\mathrm{y}}$

\begin{tabular}{|c|c|c|c|c|}
\hline Isolate & Origin & Species & Host, habitat & Reference $^{\mathrm{z}}$ \\
\hline ATCC 28344 & Florida & Sterile basidiomycete & Bean & 3 \\
\hline ATCC 34736 & Pennsylvania & Agaricus arvensis & Grass & 29 \\
\hline ATCC 48619 & Canada & Coprinus kubickae & Bentgrass & 30 \\
\hline ATCC 52208 & Czech. & Lepista sordida & Meadow & N/A \\
\hline ATCC 76404 & Massachusetts & Marasmius oreades & Grassland & 10 \\
\hline ATCC 76322 & ATCC & Marasmius siccus & Unknown & N/A \\
\hline ATCC 76415 & ATCC & Marasmius graminum & Various grasses & 10 \\
\hline Lp3 & Japan & Bovista dermoxantha & Bentgrass & 39 \\
\hline NC-BR1 & North Carolina & Agaricus campestris & Bermudagrass & 1,25 \\
\hline NC-BR2 & $\mathrm{NC}$ & Parasola pliicatilis & Bermudagrass & 1,25 \\
\hline NC-OAK & $\mathrm{NC}$ & Lycoperdon marginatum & Under oak tree & 7 \\
\hline NC-RPU & $\mathrm{NC}$ & Lycoperdon marginatum & Bermudagrass & 7 \\
\hline NC-TF1 & $\mathrm{NC}$ & Lepista nuda & Tall fescue & 1,25 \\
\hline PSU-FW1 & Pennsylvania & Agrocybe aegerita & Perennial ryegrass & N/A \\
\hline PSU-FW2 & Pennsylvania & Coprinus comatus & Perennial ryegrass & N/A \\
\hline Vp1 & Japan & Vascellum curtisii & Unknown & 39 \\
\hline
\end{tabular}

y Reference isolates are either known fairy ring-causing species or represent genera containing known fairy ring species. The authors identified reference

isolates of North Carolina (NC) origin with the morphology of the mature basidiocarp using the references noted. Reference isolates from other sources (American Type Culture Collection [ATCC], Pennsylvania, and Japan) were identified by the contributor. Reference isolate identification was substantiated by sequence similarity of the internal transcribed spacer region with GenBank accessions.

${ }^{\mathrm{z}} \mathrm{N} / \mathrm{A}=$ reference unavailable. 
Peridium thin, fragile. Gleba grayish or ash-colored, with irregularly subglobose peridioles resembling grains of sand. Basidiospores smooth, ellipsoid, brown, 3 to $4 \mu \mathrm{m}$ in diameter, with hyaline pedicels 0.5 to $1.5 \mu \mathrm{m}$ long. No capillitium or paracapillitium. In culture, white, woolly colonies with secta, and hyphae with no clamp connection.

Bovista dermoxantha (Vittad.) de Toni (=Lycoperdon dermoxanthum Vittad., B. pusilla (Batsch) Pers.; L. pusillum Batsch) (38). Samples NCP34 and SCP2. Basidocarp subglobose, sessile, 1.0 to $2.0 \mathrm{~cm}$ in diameter with rhizomorphs. Exoperidium white, thin and flaky, with capillitial threads, and a distinct apical pore. Endoperidium white and persistent. Gleba yellow at maturity with no subgleba present. Capillitium hyphae yellow-brown, 4.5 to $5.0 \mu \mathrm{m}$ wide, branched, aseptate, sclerified, pitted, and cyanophilic. Spores yellow, globose, 4.5 to $5.0 \mu \mathrm{m}$ in diameter, frequently with pedicels 0.5 to $1.0 \mu \mathrm{m}$ long. In culture, white, woolly colonies without secta, and hyphae with no clamp connection.

Vascellum curtisii (Berk.) Kreisel (=Lycoperdon curtisii Berk.) (21,38). Samples HIP1, NCP49, and NCP9. Basidiocarp subglobose, sessile, 2 to $2.5 \mathrm{~cm}$ in diameter. Exoperidium white with distinct echinulations. Endoperidium white and tough. Gleba brown at maturity with a subgleba without a distinct diaphragm. Paracapillitium hyaline, septate, thin-walled, 6 to $7.5 \mu \mathrm{m}$ wide, without pores, and acyanophilic. Spores yellow brown, globose, 2 to $2.5 \mu \mathrm{m}$ in diameter, verruculose, often with pedicels 0.5 to 1.0 $\mu \mathrm{m}$ long. In culture, pale yellow, thin, colonies with secta, and hyphae with no clamp connection.

The morphology of specimens of $V$. curtisii and B. dermoxantha was identical to the description given of fairy ring species by Terashima et al. (38), except that the paracapillitium in our specimens was wider and no diaphragm was observed.

Isolation from soil. Sixteen isolates (23\% of total isolates) obtained from infested soils were identified as fairy ring fungi with phylogenetic analysis. Isolates were solely obtained from soil blocks, with mycelium typically occurring after 7 to 14 days of incubation. Due to contamination by nontarget fungi, no isolates of fairy ring fungi were recovered from washed organic matter. Isolates obtained from soil blocks did not display any morphological characters in culture useful for speciation. Seven isolates produced hyphae with clamp connections in culture (NCSB1, NCSB2, NCSB3, NCP36, NCP37, NCP38, and OKSB1).

Soil DNA extraction and direct sequencing. The ITS1, 5.8S rRNA, and ITS2 regions were amplified with primers ITS 1f/4b for 51 of the 61 soil DNA extracts. Direct sequencing was successful in 29 of these amplicons, and the resulting sequences were added to the data set for phylogenetic analysis. Direct sequencing was not possible for 22 amplicons due to multiple peaks in the fluorogram, indicating a mixed DNA template and potential co-amplification of more than one basidiomycete species.

Amplification and direct sequencing of the ITS1, 5.8S rRNA, and ITS2 regions was also successful for samples NCSX7, NCSX8, NCSX9, and NCSX12 collected from asymptomatic areas. A BLAST search showed closest similarity (92\%) of the four samples to a GenBank accession of Arrhenia griseopallida (PGU66436), a basidiomycete species commonly associated with soil organic matter but not known to be a cause of fairy rings.

Molecular characterization. Phylogenetic analysis of the partial nSSU rDNA, nuclear ribosomal ITS regions, 5.8S, and partial nLSU DNA genes of a subset of samples revealed two distinct clades corresponding to a puffball and mushroom type of basidiocarp morphology (Fig. 1). Due to large sequence dissimilarity, specific phylogenetic analysis of the rDNA-ITS sequence using the Kimura two-parameter model was performed separately for the two clades.

In the puffball clade, phylogenetic analysis of rDNA-ITS sequences revealed three distinct clades designated A, B, and C (Fig. 2). Clade A contained a reference isolate and GenBank accession of $B$. dermoxantha (AB067224), as well as 25 sequences obtained from 16 sites in California $(n=1)$, Florida $(n=5)$, Indiana $(n=1)$, Illinois $(n=1)$, South Carolina $(n=1)$, North Carolina $(n=6)$, and
Wisconsin $(n=1)$. Sequences of the ITS region of $B$. dermoxantha were recovered from the basidiocarp $(n=9)$, soil block $(n=7)$, and soil DNA extracts $(n=9)$. Clade B contained a GenBank accession of Arachnion album (EU833649) and 14 sequences obtained from seven sites in Florida $(n=1)$, South Carolina $(n=1)$, and North Carolina $(n=5)$. Sequences of the ITS region of A. album were recovered from the basidiocarp $(n=9)$ and from soil DNA extracts $(n=5)$. Clade $\mathrm{C}$ contained a GenBank accession and reference isolate of $V$. curtisii (AB067225), and 49 sequences obtained from 10 sites in Hawaii $(n=1)$, North Carolina $(n=8)$, and Virginia $(n=1)$. Sequences of the ITS region of $V$. curtisii were recovered from the basidiocarp $(n=30)$, soil block $(n=7)$, and soil DNA extracts $(n=$ 12 ). Reference isolates and GenBank accessions of $L$. perlatum Pers. were in a separate clade. Three puffball sequences (NCP6, NCP14, and NCP20) were not resolved to any distinct clade and showed less than $98 \%$ similarity to any GenBank accession.

Within the mushroom group, several clades were apparent (Fig. 3 ). No reference isolates or mature basidiocarps were collected that matched sequences in this group; therefore, definitive speciation of our unknowns was not possible. Two of the clades, however, contained GenBank accessions with fungi reported to cause fairy rings. Clade D contained four sequences from North Carolina $(n=$ $3)$ and Oklahoma $(n=1)$ that grouped with GenBank accessions of various Coprinus spp. Clade $\mathrm{E}$ contained two sequences from North Carolina $(n=1)$ and Illinois $(n=1)$ that grouped with GenBank accessions of various Marasmius spp. Many other sequences were collected, particularly from isolations of clamp-connected hyphae from fairy-ring-infested soils, which were not similar to GenBank accessions or reference isolates of known fairy ringforming fungi.

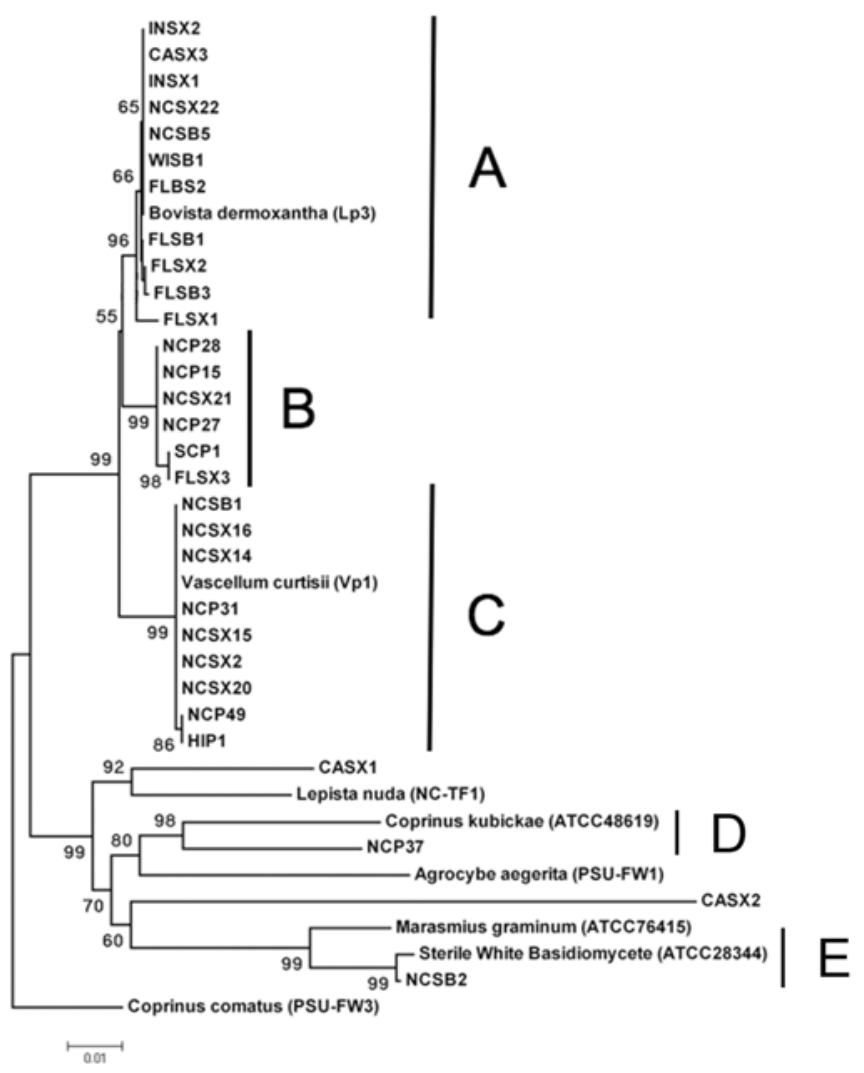

Fig. 1. Neighbor-joining phylogram of samples and reference isolates produced from sequences of ribosomal DNA (rDNA) regions partial nuclear small-subunit rDNA, internal transcribed spacer (ITS)1, 5.8S, ITS2, and partial nuclear largesubunit rDNA. Letters indicate the puffball and mushroom clades containing known fairy ring species found in this study. Scale bar indicates the horizontal distance corresponding to genetic distance as calculated by the Kimura two-parameter model. Bootstrap values are indicated adjacent to nodes and are based on 1,000 resamplings of the data set. Samples and reference isolates are listed in Table 1 and Table 2, respectively. 
Only one fairy ring species was detected per individual sample. Identical ITS amplicons were obtained from individual samples from sites in Hawaii, North Carolina, and Wisconsin using more than one of the methods described. These sequences were recovered from isolates from the basidiocarp and soil block (site 10), an isolate from the basidiocarp and soil DNA extraction (site 14), and isolates from the soil block and soil DNA extraction (sites 17, 25, 33 , and 35).

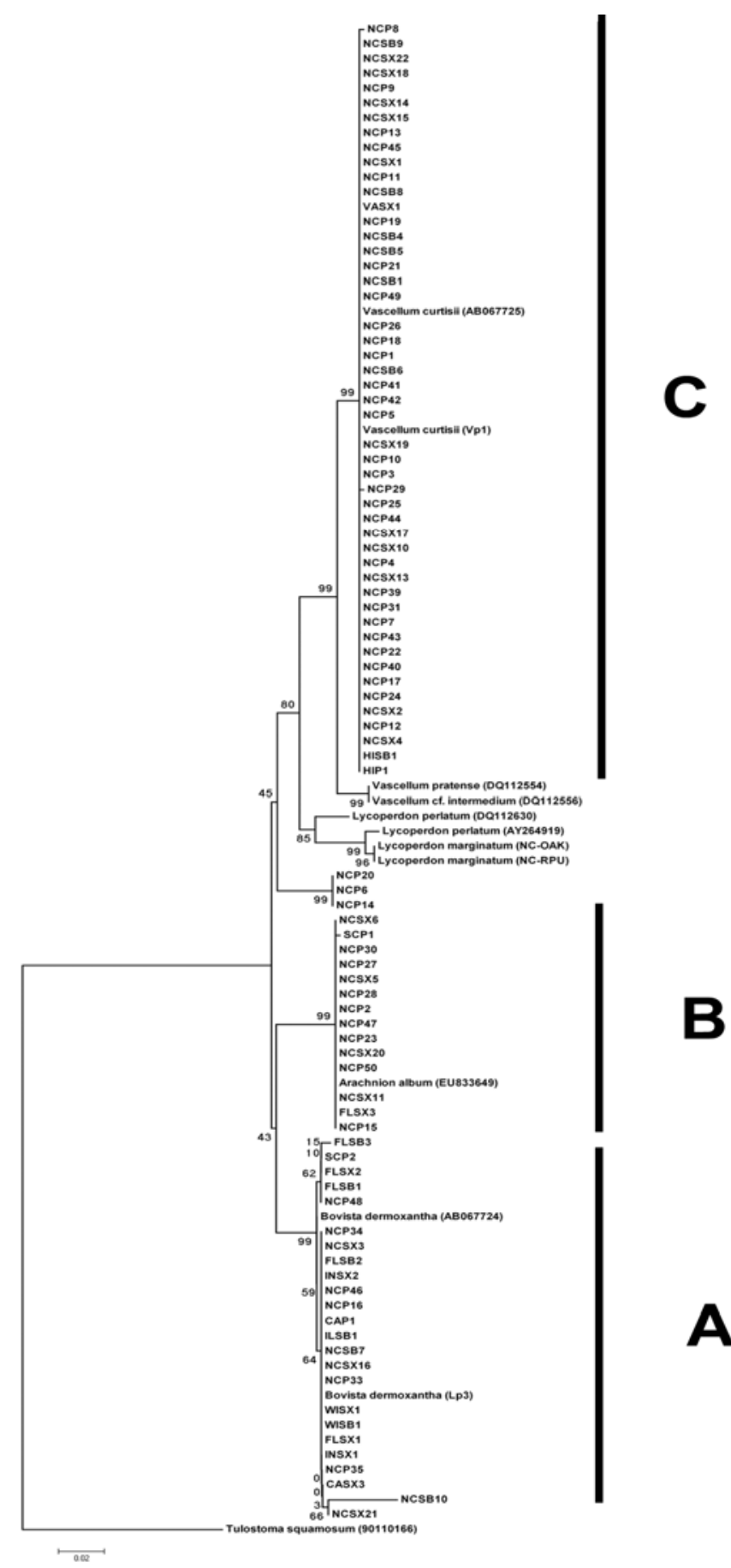

Fig. 2. Neighbor-joining phylogram of samples, reference isolates, and GenBank accessions from the puffball clade produced from sequences of ribosomal DNA regions internal transcribed spacer (ITS)1, 5.8S, and ITS2. Letters indicate the puffball clades containing known fairy ring species found in this study. Scale bar indicates the horizontal distance corresponding to genetic distance as calculated by the Kimura two-parameter model. Bootstrap values are indicated adjacent to nodes and are based on 1,000 resamplings of the data set. Samples and reference isolates are listed in Table 1 and Table 2, respectively. GenBank accessions listed with accession number.
Sequences were obtained from different putting greens at one site in Indiana and six sites in North Carolina. At two of these sites (sites 13 and 15), only one fairy ring species was detected per location. However, sequences grouping with $A$. album and $B$. dermoxantha (clade $\mathrm{A}$ and $\mathrm{B}$ ) occurred at site 15 , sequences grouping with $B$. dermoxantha and $V$. curtisii (clade B and C) were detected at site 24 , and sequences grouping with $A$. album, B. dermoxantha, and $V$. curtisii (clades A to C) were obtained from sites 16 and 20.

\section{Discussion}

Identification of fairy ring pathogens has historically been a difficult task, relying solely on morphological characteristics of mature basidiocarps. The majority of our samples were obtained from immature puffballs, soil block isolations, and soil DNA extracts which would have been unidentifiable by traditional methods. We were able to find several mature basidiocarps as a base for morphological identification; however, approximately 93\% of our unknown fairy ring isolates and DNA sequences would have been unidentified if only this method was employed.

Three species of Lycoperdaceae were consistently identified as fairy ring pathogens based on basidiocarp morphology and high similarity of ITS sequences with reference isolates and GenBank accessions. This is the first known association of A. album with fairy ring symptoms. A. album was originally described by Schweinitz from specimens collected in North Carolina and is widely distributed throughout the Eastern United States and other parts of the world $(7,20,27)$. A album is typically found in association with grasses and is common in sandy soils, including coastal sand dunes $(7,20)$. Therefore, the sand-based soil profile of a golf putting green may provide a good habitat for this fungus.

$B$. dermoxantha had the broadest geographical distribution (eight states) among the species detected in this study. This species was sampled as far north as Wisconsin, indicating that the species is adapted to overwinter and survive subzero soil temperatures. Sequences obtained from $V$. curtisii were recovered in samples from Hawaii and North Carolina. The basidiocarp of $V$. curtisii

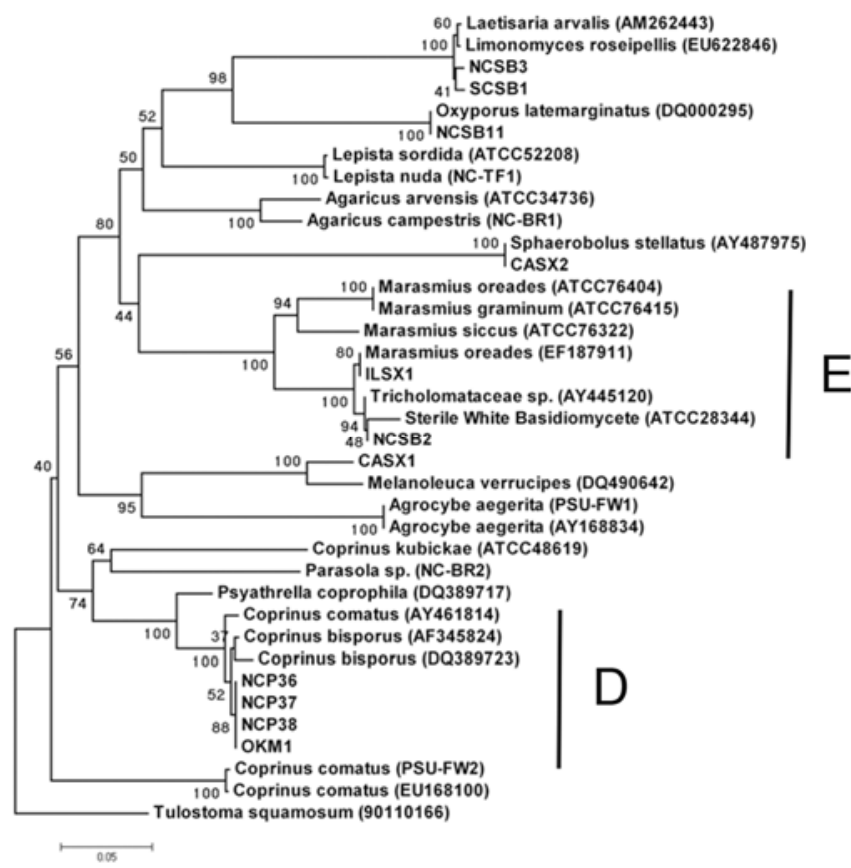

Fig. 3. Neighbor-joining phylogram of samples, reference isolates, and GenBank accessions from the mushroom clade produced from sequences of ribosomal DNA regions internal transcribed spacer (ITS)1, 5.8S, and ITS2. Letters indicate the mushroom clades containing known fairy ring species found in this study. Scale bar indicates the horizontal distance corresponding to genetic distance as calculated by the Kimura two-parameter model. Bootstrap values are indicated adjacent to nodes and are based on 1,000 resamplings of the data set. Samples and reference isolates are listed in Table 1 and Table 2, respectively. GenBank accessions listed with accession number. 
possesses peridium morphology that closely resembles L. perlatum, a frequently reported fairy ring pathogen in the Southeastern United States. We did not find L. perlatum in the current study; therefore, it is possible that $V$. curtisii has been misidentified in the past. Both $V$. curtisii and $B$. dermoxantha have been previously characterized in association with fairy rings on putting greens in Japan (38), and may be two of the more cosmopolitan causal agents of fairy rings on golf putting greens.

Different puffball species were detected from different putting greens or from the same green in different years. On one putting green in North Carolina, we identified V. curtisii from basidiocarps collected in 2007 and A. album in basidiocarps collected from the same putting green in 2009. This implies that a species complex of Lycoperdaceae could be present in putting greens, and that different species could be active under different environmental conditions. Terashima (38) reported that both $V$. curtisii and B. dermoxantha occurred on the same creeping bentgrass green in Japan but differed in time of peak basidiocarp production, with $V$. curtisii peaking in June, July, and September and B. dermoxantha peaking in July and August. If basidiocarp morphology is used to identify fairy ring pathogens, then only the pathogen producing basidiocarps at the time of sampling would be discerned. A mixture of species could also potentially complicate interpretation of sequencing results; however, it is more likely that this technique would capture the species that was currently active and inciting disease at the time of sampling.

Identification of fairy ring species within the mushroom-forming clade was not straightforward. No mature mushroom basidiocarp was available for morphological identification due to the disruption of mushroom development by frequent agronomic practices and traffic on golf greens. Definitive speciation was not possible from DNA analysis for any sample within the mushroom-forming clade due to the lack of reference isolates with highly similar ITS sequences. ITS sequences from our samples show great diversity within this clade; however, very few of the GenBank accessions or reference isolates grouping close to these samples have been linked to fairy ring occurrence in turfgrasses. However, two mushroom clades corresponding to known fairy ring species were apparent, with two sequences nested within a clade containing Marasmius spp. and four sequences nested within a clade containing Coprinus spp.

Most sampling was conducted in North Carolina, with 80 of the 105 recovered sequences originating from 16 different sites in the state. All five of the fairy ring clades detected in this study were represented in North Carolina. $V$. curtisii was detected at the most sites in this study $(n=8)$, followed by B. dermoxantha $(n=7), A$. album $(n=5)$, Coprinus spp. $(n=1)$, and Marasmius spp. $(n=1)$. A majority of the North Carolina sequences $(n=42)$ originated from the Lake Wheeler Research Facility in Raleigh, NC. The site was sampled more extensively to assess the various methods of speciation utilized in the study. At this site, all three puffball species were found in association with fairy ring symptoms. Two $A$. album sequences were recovered from basidiocarps, seven $B$. dermoxantha sequences were recovered from basidiocarps $(n=4)$ and soil DNA extracts $(n=3)$, and $V$. curtisii sequences were recovered from basidiocarps $(n=20)$, soil DNA extracts $(n=5)$, and soil block isolation $(n=1)$.

Although many regions of the country were not represented in our study, it is striking how few fairy ring fungi were detected from putting greens as opposed to the greater than 60 species reported in all landscapes. In particular, fairy ring species in the mushroom clade were under-represented compared with those reported in pastures, lawns, and landscapes. This may be due to the inadequacy of our methodologies in obtaining DNA from these species or the lack of mushroom prevalence in our sampling regions or in sand-based putting greens. The soil profile of a sand-based putting green is a unique artificial environment that has a different distribution of soil microbes and lacks the variety of organic matter sources found in natural soils. The reduced number of fairy ring species found in our study may reflect this difference in environ- ments, although an experiment with broader geographic sampling is needed to further assess this premise.

Unless basidiocarps are present, the only pathogen sign that turf diagnosticians can use to diagnose fairy ring in diseased samples is observation of clamp-connected hyphae in the soil profile. In our study, the ITS regions of two isolates with clamped hyphae (SCSB1 and NCSB3) were 99\% similar to GenBank accessions of basidiomycete species (Laetisaria arvalis Burds. and Limonomyces roseipellis Stalpers \& Loer.) not known to cause fairy rings. In addition, many species in the Lycoperdaceae family do not form clamp connections $(20,38)$, making this characteristic unreliable for diagnosis of fairy ring, as mentioned previously.

The extraction and amplification of genomic DNA from soils has been used successfully to examine the species richness of environmental samples $(5,16,23,34)$. In this study, we used soil DNA extraction to detect individual fairy ring species. Direct sequencing of soil DNA extracts with basidiomycete-specific primers was more efficient at identifying fairy ring species than traditional fungal isolation attempts with a soil block method (48 versus $23 \%$ success rate, respectively). The method is more rapid and practical but has the disadvantage of added cost. Cloning PCR products and segregating individual sequences from a mixed template could greatly increase efficiency but the added cost and time would not be acceptable in a diagnostic setting. A library of reliable speciesspecific primers for all fairy ring fungi could lead to a rapid and efficient diagnostic assay as has been done with other turfgrass diseases $(19,41,42)$. At the present time, however, sequencing of the ITS region may be the most efficient and rapid method for attempting fairy ring speciation from soil samples.

In this survey, the range of fairy ring species found on sandbased golf putting greens was not as broad as those reported on grasses grown in natural soils. We also found evidence of a species complex occurring in some locations, which could be problematic if these species vary in their periods of active growth or response to management tactics. Research targeting the biology of the major fairy ring species reported in this study may provide valuable insights into conditions that are favorable for fairy ring epidemics and enable the development of more efficient control practices.

\section{Acknowledgments}

This research was supported by grants from Bayer Environmental Science, the Environmental Institute for Golf, Carolinas Association of Golf Course Superintendents, and the Center for Turfgrass Environmental Research and Education at NC State. We thank J. Roberts and E. Rosebrough (North Carolina State University) for valuable technical assistance, and M. Fidanza (Penn State University) and Y. Terashima (Chiba Prefectural Forest Research Center, Japan) for providing fungal isolates from their collections.

\section{Literature Cited}

1. Arora, D. 1986. Mushrooms Demystified: A Comprehensive Guide to the Fleshy Fungi. Ten Speed Press, Berkeley, CA.

2. Baath, E. 1988. A critical examination of the soil washing technique with special reference to the effect of the size of the soil particles. Can. J. Bot. 66:1566-1569.

3. Bell, D. K., and Sumner, D. R. 1984. Ecology of a sterile white pathogenic basidiomycete in corn, peanut, soybean, and snap bean field microplots. Plant Dis. 68:18-22.

4. Brecht, M. O., Stiles, C. M., and Datnoff, L. E. 2005. Evaluation of fungicides for the control of fairy ring in bermudagrass, 2004. Fungic. Nematicide Tests 60:1.

5. Bridge, P., D., and Spooner, B. 2001. Soil fungi: diversity and detection. Plant Soil 232:147-154.

6. Bridge, P., D., Spooner, B. M., Roberts, P. J., and Panchal, G. 2003. On the unreliability of published DNA sequences. New Phytol. 160:43-48.

7. Coker, W. C., and Couch, J.N. . 1928. The Gasteromycetes of the Eastern United States and. Canada. University of North Carolina Press, Chapel Hill.

8. Couch, H. B. 1995. Diseases of Turfgrasses. Krieger Publishing, Malabar, FL.

9. DeBano, L. F. 2000. Water repellency in soils: a historical overview. J. Hydrol. 231-232:4-32.

10. Desjardin, D. E. 1990. Culture morphology of Marasmius species. Sydowia 42:17-87.

11. Duncan, E., and Keay, S. M. 1990. Aberrant dikaryons in the Lycoperdaceae. Mycologia 82:17-22.

12. Fidanza, M. A., and Bagwell, A. 2005. Evaluation of fungicides and a soil surfactant for curative type-II fairy ring control in creeping bentgrass, 2004. 
Fungic. Nematicide Tests 60:1

13. Fidanza, M. A., Sanford, D. L., Wetzel, H., and Nattle, J. S. 2003. Evaluation of fungicides and soil wetting agents for fairy ring management on creeping bentgrass, 2001. Fungic. Nematicide Tests 58.

14. Fidanza, M. A., Sanford, D. L., Wetzel, H., and Nattle, J. S. 2003. Evaluation of fungicides, a soil wetting agent, and cultural practices for curative fairy ring control. Fungic. Nematicide Tests 58.

15. Frankland, J. C., Dighton, J., and Boddy, L. 1990. Methods for studying fungi in soil and forest litter. Methods Microbiol. 22:343-404.

16. Gardes, M., and Bruns, T. D. 1993. ITS primers with enhanced specificity for basidiomycetes-application to the identification of mycorrhizae and rusts. Mol. Ecol. 2:113-118.

17. Halisky, P. M., and Peterson, J. L. 1970. Basidiomycetes associated with fairy rings in turf. Bull. Torrey Bot. Club 97:225-227.

18. Jackson, N. 1972. Superficial invasion of turf by two basidiomycetes. J. Sports Turf Res. Inst. 48:20-23.

19. Kaminski, J. E., Dernoeden, P. H., O’Neill, N. R., and Wetzel, H. 2005. A PCR-based method for the detection of Ophiosphaerella agrostis in creeping bentgrass. Plant Dis. 89:980-985.

20. Kasuya, T., Orihara, T., Fukiharu, T., and Yoshimi, S. 2006. A lycoperdaceous fungus, Arachnion album (Agaricales, Arachniaceae), newly found in Japan. Mycoscience:385-387.

21. Kriesel, H. 1993. A key to Vascellum (Gasteromycetidae) with some floristic notes. Blyttia 51:125-129.

22. Leonian, L. H. 1924. A study of factors promoting pycnidium-formation in some Sphaeropsidiales. Am. J. Bot. 11:19-50.

23. Lynch, M. D. J., and Thorn, R. G. 2006. Diversity of basidiomycetes in Michigan agricultural soils. Appl. Environ. Microbiol. 72:7050-7056.

24. Martin, B. 1998. Evaluation of Heritage and Prostar for fairy ring suppression in creeping bentgrass, 1997. Fungic. Nematicide Tests 53:449.

25. Miller Jr., O. K., and Miller, H. H. 2006. North American Mushrooms: A Field Guide to Edible and Inedible Fungi. Falcon Guide, Guilford, CT.

26. O'Brien, H. E., Parrent, J. L., Jackson, J. A., Moncalvo, J., and Vilgalys, R. 2005. Fungal community analysis by large-scale sequencing of environmental samples. Appl. Environ. Microbiol. 71:5544-5550.

27. Pérez-Silva, E., Valle, M. E., and Herrera, T. 1994. Contribution to the knowledge of Gasteromycetes of Sonora, Mexico. Rev. Mex. Mycol. 10:77101.

28. Porter, T. M., Skillman, J. E., and Moncalvo, J. 2008. Fruiting body and soil rDNA sampling detects complementary assemblage of Agaricomycotina (Basidiomycota, Fungi) in a hemlock-dominated forest plot in southern Ontario. Mol. Ecol. 17:3037-3050.
29. Raper, C. A., and Kaye, G. 1978. Sexual and other relationships in the genus Agaricus. J. Gen. Microbiol. 105:135-151.

30. Redhead, S. A., and Smith, J. D. 1981. A North American isolate of Coprinus kubickae associated with a superficial fairy ring. Can. J. Bot. 59:410414.

31. Shantz, H. L., and Piemesel, R. L. 1917. Fungus fairy rings in eastern Colorado and their effect on vegetation. J. Agric. Res. 11:191-245.

32. Smith, A. H. 1951. Puffballs and Their Allies in Michigan. University of Michigan Press, Ann Arbor.

33. Smith, J. D., Jackson, N., and Woolhouse, A. R. 1989. Fungal Diseases of Amenity Turfgrasses. E \& F.N. Spon Ltd., London.

34. Sobek, E. A and Zak, J. C. 2003. The Soil FungiLog procedure: method and analytical approaches to understanding fungal functional diversity. Mycologia 95:590-602.

35. Stiles, C. M., Harmon, P. F., Brecht, M. O., and Datnoff, L. E. 2007. Evaluation of new fungicides and surfactants for the management of fairy ring associated with Lycoperdon sp. in bermudagrass. Appl. Turf. Sci.:[1-10].

36. Swartz, D. 1933. Some cultural characters of species of Lycoperdaceae. Am. J. Bot. 22:505-566.

37. Tamura, K., Dudley, J., Nei, M., and Kumar, S. 2007. MEGA4: Molecular Evolutionary Genetics Analysis (MEGA) software version 4.0. Mol. Biol. Evol. 24:1596-1599

38. Terashima, Y., Fukiharu, T., and Fujiie, A. 2004. Morphology and comparative ecology of the fairy ring fungi, Vascellum curtisii and Bovista dermoxantha, on turf of bentgrass, bluegrass, and Zoysiagrass. Mycoscience 45:251-260.

39. Terashima, Y., Ogiwara, K., Kojima, M., Kubo, C., Seki, A., and Fujiie, A 2002. Primers based on specific ITS sequences of rDNAs for PCR detection of two fairy ring fungi of turfgrass, Vascellum pratense and Lycoperdon pusillum. Mycoscience 43:261-265.

40. Thorn, R. G., Reddy, C. A., Harris, D., and Paul, E. A. 1996. Isolation of saprophytic basidiomycetes from soil. Appl. Environ. Microbiol. 62:4288 4292.

41. Tisserat, N., Hulbert, S. H., and Sauer, K. M. 1994. Selective amplification of rDNA internal transcribed spacer regions to detect Ophiosphaerella korrae and $O$. herpotricha. Phytopathology 84:478-482.

42. Vincelli, P., and Tisserat, N. 2008. Nucleic acid-based pathogen detection in applied plant pathology. Plant Dis. 92:660-669.

43. Warcup, J. H. 1951. Studies on the growth of basidiomycetes in soil. Ann. Bot. 15:305-318.

44. York, C. A., and Canaway, P. M. 2000. Water repellent soils as they occur on UK golf greens. J. Hydrol. 231:126-133. 